\title{
Diarrheal disease and enteric infections in LMIC communities: how big is the problem?
}

\author{
Benjamin J. J. McCormick and Dennis R. Lang ${ }^{1,2^{*}}$
}

\begin{abstract}
Studies of enteric diseases have historically focused on observations of clinical diarrhea as a cause of mortality and morbidity. Emerging evidence suggests that diarrhea dramatically underestimates both exposure to enteropathogens and the long-term consequences arising from infection. High burden of pathogens in the gut, even in the absence of diarrhea, is common in infants in low and middle income countries. Continual challenge by pathogens, in conjunction with an inadequate diet stimulates an inflammatory disease that alters the structure of the gut, metabolic and immunological pathways and changes the microbiome. Both diarrhea and enteropathogen infection have been associated with reduced growth, reduced cognitive development, and reduced vaccine efficacy suggesting that the burden of diarrheal disease is dramatically underestimated.
\end{abstract}

Keywords: Enteric pathogens, Malnutrition, Enteropathy, Diarrhea, Cognitive development, Growth, Vaccine response, Sanitation and hygiene

Abbreviations: DALYs, Disability Adjusted Life Years; EE, environmental enteropathy; GEMS, Global Enteric Multicenter Study; LMIC, low and middle income countries; MAL-ED, The Etiology Risk Factors and Interactions of Enteric Infections and Malnutrition and the Consequences for Child Health and Development; SBBO, small bowel bacterial overgrowth; UNICEF, United Nations Children's Emergency Fund; WASH, Water Adequate Sanitation and Hygiene

\section{Background}

\section{The importance of diarrheal disease}

The importance of diarrhoeal disease to child development in low and middle income countries (LMIC) was highlighted by seminal work in the 1950s and '60s [1,2]. Subsequent research over the next two decades focused on quantifying health outcomes by the frequency and severity of symptoms [3]. Interventions to interrupt transmission routes [4-6] have simultaneously greatly reduced mortality [7] and rates of diarrheal incidence [8]. Nevertheless, continuing interest in diarrhea reflects its role as the second most common cause of death in children under 5 years old [9].

The burden of diarrhea, however, is not solely estimated by mortality. It is a proximate driver of

\footnotetext{
* Correspondence: lang4@fnih.org

${ }^{1}$ Fogarty International Center, National Institutes of Health, Bethesda, MD, USA

${ }^{2}$ Foundation for the National Institutes of Health, Bethesda, MD, USA
}

malnutrition [10], and related to many insidious morbidities $[3,11]$. A considerable body of evidence has rearranged the linear United Nations Children's Emergency Fund (UNICEF) framework [10] of malnutrition into a cyclical conceptual model that describes a vicious cycle of poverty' [11] (Fig. 1): (a) infection with enteric pathogens is associated with b) impaired gut-function [12-15] that can (c) exacerbate effects of malnutrition [16], for example, restricting appropriate processing of nutrients $[17,18]$ necessary for (d) physical [17-20] and (e) cognitive development [21-23] as well as (f) altering immune responses [16, 24], thereby impairing a child's ability to resist a) recurrent infections $[17,25]$ and illness $[26]$. Scaling to a population from an individual, malnutrition as a disease associated with poverty increases (g) behaviors and environments that propagate the syndrome. It is worth noting that the language of the vicious cycle has evolved from a focus on diarrhea [27] to specifically implicating enteropathogen infection absent diarrhea $[11,28]$. Advances in diagnostics 


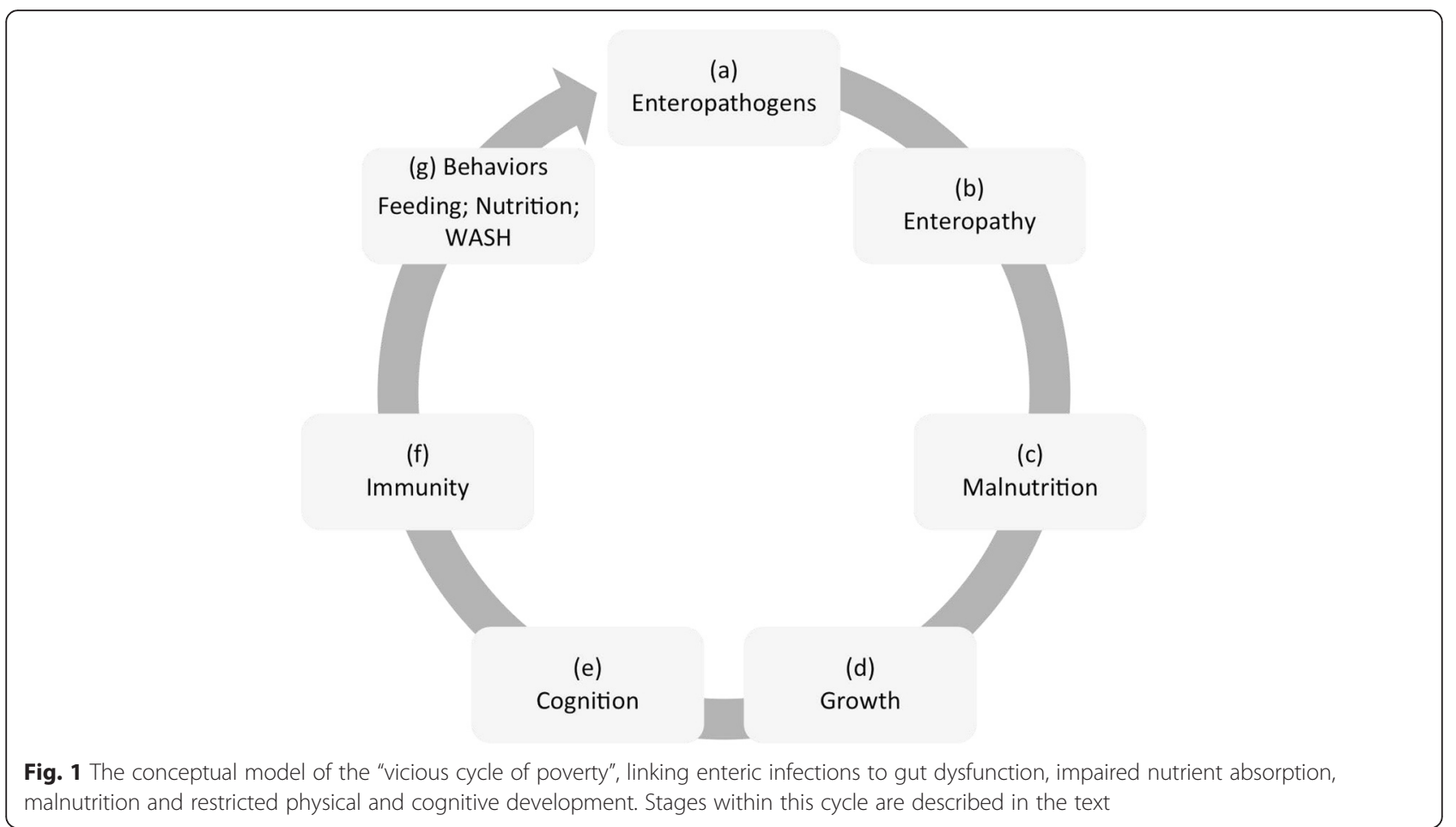

are likely to provide further evidence for the role of cryptic infections in the absence of overt symptoms.

\section{Main text}

\section{Diarrhea and enteropathogens}

Recorded rates of diarrhea are unlikely to reflect the true prevalence of disease and thereby dramatically underestimate the untoward consequences of enteropathogen infections. In England where care is readily available, unreported diarrhea was 5.8 times higher than those that were recorded [29] and in Canada only $10 \%$ of adults sought care [30]. Where symptoms are considered common or expected, they are less likely to be reported.

Early research focused on diarrheal symptoms on the presumption that childhood diarrhea in LMIC settings was the product of underlying infection [31]. Identification of which pathogen was causing diarrhea was just awaiting development of methods of detection. In the 1960s recovering a pathogen from diarrheal stool was seldom possible in more than $40 \%$ of cases. For recent studies the challenge has been to ascribe causation between the many pathogens detected, either in the same stool or given the high rates of detection in the absence of diarrhea. In the MAL-ED study $76.9 \%$ diarrheal stools and $64.9 \%$ of non-diarrheal stools had at least one pathogen detected and $41.0 \%$ and $29.0 \%$, respectively, had at least two [32]. Similarly in the Global Enteric Multicenter Study (GEMS), though examining moderate to severe diarrhea rather than the prospective community cohort of MAL-ED, found a comparable
$83 \%$ of cases and $72 \%$ of controls had at least one pathogen, with two or more identified in $45 \%$ cases and $31 \%$ controls [33]. Rates of detection regardless of coincident symptoms are only likely to rise as more sophisticated technology (e.g. qPCR) enables both increased rates of detection as well as quantitation of pathogen burden $[34,35]$.

The attribution of diarrhea to specific pathogens is more challenging when they are coincident, although estimates appear remarkably similar to those of the 1960s when a single pathogen was detected in stool. In GEMS, an average of $44 \%$ cases of moderate-to-severe diarrhea in infants and $47 \%$ of cases in toddlers were attributed to pathogens. MAL-ED attributed $19.1 \%$ and $33.1 \%$ of diarrheal episodes in the first and second year of life respectively to enteropathogens. Even if pathogens appear less causally linked to diarrhea than previously expected, the high prevalence of these organisms in the absence of diarrhea raises the question of whether or not these organisms are causing more covert damage?

\section{Enteropathogens and enteric disease}

Histopathogical studies, dating back to the 1960s, of intestinal biopsy samples revealed physiological and functional changes in the gut - villus atrophy and crypt hyperplasia [36-38] that have been attributed to living in an environment where repeated enteropathogen infections were common [39]. In an effort to find noninvasive diagnostics and the absence of overt pathognomonic symptoms, a growing collection of biomarkers 
$[40,41]$ are emerging that can detect reduced absorptive capacity [39, 42], increased permeability [43] and chronic intestinal inflammation [44, 45] that have become indicative of an inflammatory condition induced by enteropathogens called environmental enteropathy (EE) $[46,47]$.

Many studies have examined biomarkers of EE and found associations between EE and malnutrition. The ratio of lactulose to mannitol, as an indicator of absorptive capacity and/or breaches of the mucosal barrier has explained as much as $42.9 \%$ of linear and $38.9 \%$ of weight variability [43] though not consistently in other populations $[48-50]$. This variability may be attributed to differences in testing procedure, test sensitivity [51,52], or to variability in how populations process the two sugars to drive the ratio [39] and their individual analysis (sometimes categorized rather than continuous). Another individual biomarker of inflammation, REG1B, explained around $1.5 \%$ of linear growth variation [53]. However, using a broader spectrum of EE biomarkers to capture multiple aspects of the syndrome achieved a description of $46.3 \%$ of linear growth variation [24].

Exciting new understanding is emerging from mouse models that offer not just confirmation of EE, but also causal explanation. Mice fed a malnourished diet to mimic diets of children in Bangladesh exhibited $30 \%$ reduction in weight gain, however it was only when malnourished mice were additionally exposed to gut bacteria that they developed similar gut lesions found by histopathology [16]. The addition of a Bacteroidales and E. coli cocktail exacerbated much of the intestinal damage of moderate malnutrition including altering bacterial colonisation, inflammation and immunity to other enteropathogens. However, enteropathogens importantly interact with the commensal microbiome [54, 55], which is shaped by diet [56-58]. In malnourished children the gut microbiota remains immature and its composition and colonisation patterns fail to mature with age as the microbiota does in well-nourished children. Dietinduced changes to the gut environment along with frequent exposure to new microbes result in demonstrable changes in immune and metabolic pathways $[16,59,60]$. Relating the pathways found within mouse models to observational studies in humans using biomarkers is proving more difficult, but EE does provide a mechanistic link between enteropathogen exposure and undernutrition to growth and development.

\section{Infection and growth}

Because it is easily identified, most studies have relied on diarrheal symptoms as an indication of enteropathogen infection. Diarrhea has long been associated with growth shortfall; 5, 11 and $20 \%$ of reduced linear growth in Mexico, Guatemala and Bangladesh respectively [61-63].
A pooled analysis of nine studies found consistent associations between diarrhea and stunting with $25 \%$ of stunting prevalence at 2 years old attributed to children with $\geq 5$ diarrhoeal episodes, or alternatively $18 \%$ of stunting attributed to children who had diarrhoea on $\geq 2 \%$ of days from birth to 24 months [64]. Improving sanitation and hygiene has been predicted to reduce stunting by $6 \%$ [65] and even reduce all-cause mortality by $4 \%$ [66].

Quantifying the contribution of individual pathogens to growth shortfalls has been less frequently examined. E. coli and Shigella were associated with decreased weight and length respectively in Bangladesh [63] and in addition to these pathogens, infection with Campylobacter was associated with reduced linear growth in Peru [20]. Pathogens, for example Cryptosporidium and Campylobacter, in diarrhea are associated with greater growth deficits than those with no symptoms $[67,68]$ though the prevalence of the latter is likely to be more common.

Whilst pathogens and diarrhea have been associated with reduced growth, the effects can be reversible. For example, weight loss following infection with Shigella could be reversed with improved diet [69]. In some cases growth retardation caused by transient infection can recover without intervention [19]. Repeated infections diminish the ability to achieve catch-up growth to compensate for growth shortfall [70, 71].

\section{Infection and oral polio vaccine}

Malnutrition, has been implicated as a reason for the disappointing efficacy of oral vaccines in developing countries [72-74]. Diarrhea at the time of oral polio vaccine (OPV) reduces the odds of seroconversion to 0.68 [75], and malnutrition reduced OPV titers by half [76]. Similarly, rotavirus vaccine efficacy, important because of the association between rotavirus and diarrhea [32, 33], is only $51 \%$ in developing regions [77] and illness (both diarrheal and respiratory) both during or after measles vaccination can result in reduced titers [78].

Individual pathogens, in addition to contributing to overt illness and general malnutrition, can impair vaccine efficacy. Plasma phagocytic activity, for example is reduced by enterotoxigenic $E$. coli, which additionally reduced complement C3 levels by $50 \%$ [79]. Ascaris infections and small bowel bacterial overgrowth (SBBO) reduced CVD 103-HgR cholera vaccine response $[80,81]$. SBBO is associated with gut inflammation [82], an important component of $\mathrm{EE}$ which can result in modulation of immune pathways [16, $24]$ that can, along with gut microbiota [54, 83], reduce the efficacy of vaccines. Mechanisms can include production of small molecules that are cross-reactive with oral vaccines and increased mucosal lymphoctyes and plasmacytes, and notably T-cells $[16,44]$. Levine 
[74] suggests two explanations, one in which EE elicits a chronically pro-inflammatory state that protects against repeated infection, while at the same time diminishing response to orally delivered live vaccines. Alternatively, a second possibility is that active immune responses are dampened as the gut microbiota and host immunity is modified so that pathogens are tolerated rather than cleared $[84,85]$.

\section{Infection and cognitive development}

As diarrheal disease disrupts nutrient processing and metabolic pathways, one postulated consequence of the vicious cycle is that repeated infections impair cognitive development. Correlative evidence gives some support to this idea, with numerous studies demonstrating that stunted children perform less well in early assessment of cognitive performance and that early tests of cognitive development are predictive of school readiness and achievement [86]. More specifically, studies have observed that higher rates of diarrhea [23, 87] and some pathogens [21, 88-90] delay school-readiness though results are disputable when other correlated factors are accounted for, such as underlying poverty or malnutrition $[89,91]$.

The consequence of impaired cognitive development, most of which has associated with poverty is estimated to reduce adult income by $5.9 \%$, and, when combined with stunting, reduces income by $30.1 \%$ [86]. This is largely the result of lost years of primary schooling, through delayed school readiness, high drop-out rates or reduced learning whilst at school [92], each of which is estimated to account for a drop of 6.8 to $10.6 \%$ in adult wages [93]. With reduced wages, the vicious cycle is perpetuated, with negative effects on future generations and populations.

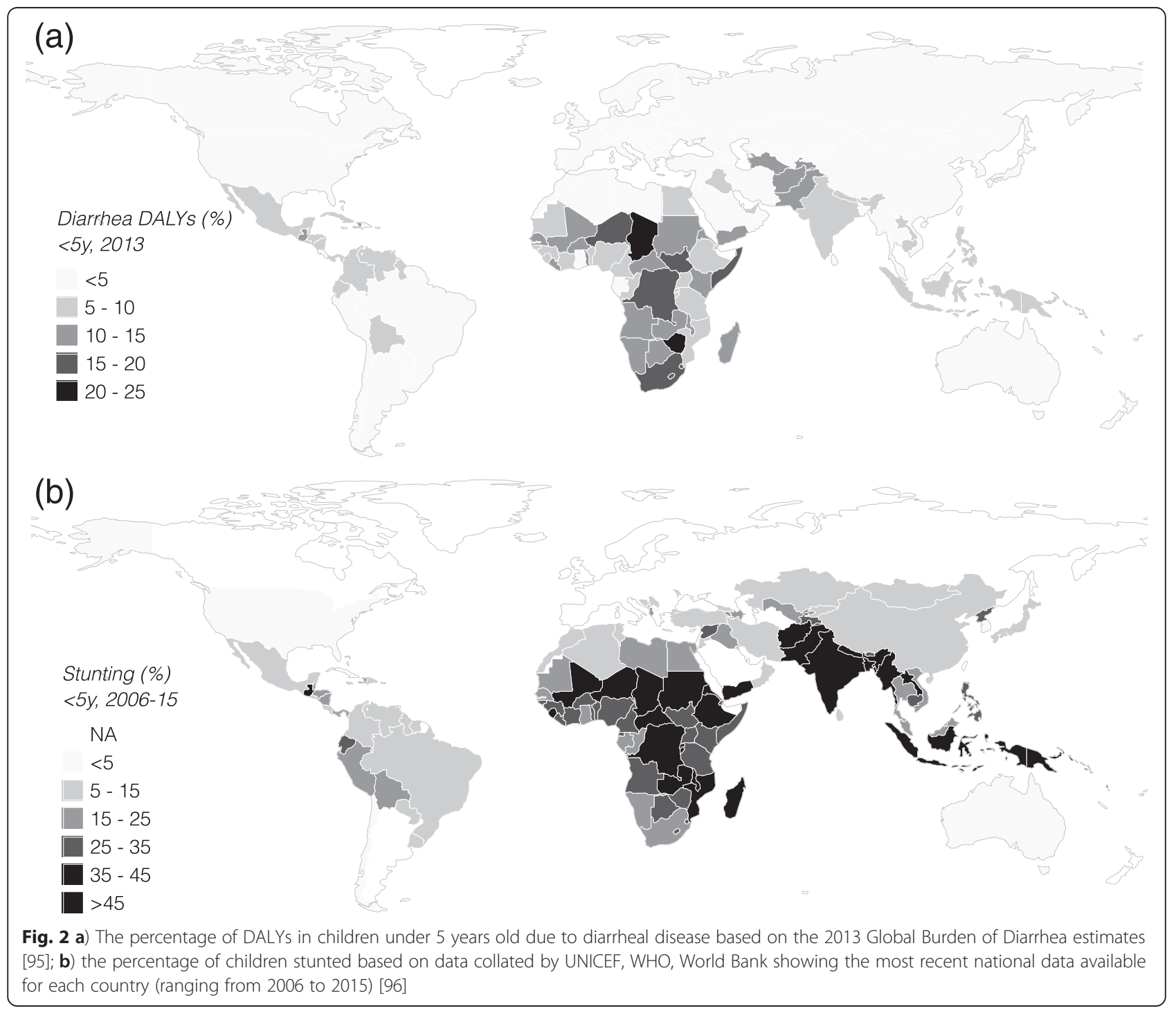




\section{Conclusions}

A mounting body of evidence suggests that the burden of diarrhea is much greater than the high reported number of childhood deaths each year. The insidious morbidity ascribed to diarrheal disease is more appropriately attributed to enteric infection.

Guerrant et al. [94] offered a first attempt to revise estimates of diarrheal disease Disability Adjusted Life Years (DALYs) (Fig. 2). Rather than base $95 \%$ of the burden on mortality, they accounted for long-term consequences and suggested a conservative doubling of the disease burden. As further data become available that can better identify and quantify long-term health effects of asymptomatic enteric infection, this estimate is likely to be refined, and will almost certainly be increased, for example, accounting for at least some of burden of stunting, which is substantially greater than reflected by current DALY estimates due to diarrhea per se (Fig. 2).

By explicitly recognising the importance of exposure to pathogens, singly or in combination, and not being guided solely by the symptom of diarrhea, targeted efforts to reduce the compounded damage due to inadequate diet and infection may yield greater success than reducing either separately. It suggests that increased emphasis should be placed on improving access to clean water, adequate sanitation and hygiene (WASH) methodologies that attempt to break transmission routes that are common to many pathogens along side targeted vaccination against high priority pathogens.

\section{Acknowledgments}

The authors thank the staff and participants of the MAL-ED Network Project for their important contributions. The authors especially thank Michael Gottlieb, Karen Tountas, Laura Caulfield and Richard Guerrant for their insight and assistance in writing this manuscript.

\section{Funding}

The Etiology, Risk Factors and Interactions of Enteric Infections and Malnutrition and the Consequences for Child Health and Development Project (MAL-ED) is carried out as a collaborative project supported by the Bill \& Melinda Gates Foundation, the Foundation for the NIH and the National Institutes of Health/Fogarty International Center. The funders had no role in the writing of the manuscript.

\section{Availability of data and supporting materials} Not applicable.

\section{Author's contributions}

BJJM and DRL contributed equally to the writing of this manuscript. Both authors read and approved the final manuscript.

\section{Competing interests}

The authors declare that they have no competing interests.

\section{Consent for publication}

Not applicable.

\section{Ethics approval and consent to participate}

Not applicable.

Received: 12 May 2016 Accepted: 13 July 2016

Published online: 19 July 2016

\section{References}

1. Scrimshaw NS, Taylor CE, Gordon JE. Interactions of nutrition and infection. Monogr Ser World Health Organ. 1968;57:3-329.

2. Mata LJ, Urrutia JJ, Gordon JE. Diarrhoeal disease in a cohort of Guatemalan village children observed from birth to age two years. Trop Geogr Med. 1967:19:247-57.

3. Black RE, Allen LH, Bhutta ZA, Caulfield LE, de Onis M, Ezzati M, et al. Maternal and child undernutrition: global and regional exposures and health consequences. Lancet. 2008;371:243-60.

4. Sedgwick WT, Macnutt JS. On the Mills-Reincke Phenomenon and Hazen's Theorem concerning the decrease in mortality from diseases other than typhoid fever following the purification of public watersupplies. J Infect Dis. 1910;7:489-564.

5. Blaise $H$, Yongsi N, Dovie DBK. Diarrheal diseases in the history of public health. Arch Med Res. 2007;38:159-63.

6. Wagner EG, Lanoix JN. Excreta Disposal for Rural Areas and Small Communities WHO Monograph 39. Geneva, Switzerland: World Health Organization; 1958.

7. Kosek M, Bern C, Guerrant RL. The global burden of diarrhoeal disease, as estimated from studies published between 1992 and 2000. Bull World Health Organ. 2003;81:197-204.

8. Walker CLF, Perin J, Aryee MJ, Boschi-Pinto C, Black RE. Diarrhea incidence in low- and middle-income countries in 1990 and 2010: a systematic review. BMC Public Health. 2012;12:220.

9. Liu L, Oza S, Hogan D, Perin J, Rudan I, Lawn JE, et al. Global, regional, and national causes of child mortality in 2000-13, with projections to inform post-2015 priorities: an updated systematic analysis. Lancet. 2015;385:430-40.

10. UNICEF. Strategy for improved nutrition of children and women in developing countries. New York: UNICEF; 1990.

11. Guerrant RL, Oriá RB, Moore SR, Oriá MO, Lima AA. Malnutrition as an enteric infectious disease with long-term effects on child development. Nutr Rev. 2008;66:487-505.

12. Salazar-Lindo E, Allen S, Brewster DR, Elliott EJ, Fasano A, Phillips AD, et al. Intestinal infections and environmental enteropathy: Working Group report of the second World Congress of Pediatric Gastroenterology, Hepatology, and Nutrition. J Pediatr Gastroenterol Nutr. 2004;39 S2:S662-9.

13. Petri WA, Miller M, Binder HJ, Levine MM, Dillingham R, Guerrant RL. Enteric infections, diarrhea, and their impact on function and development. J Clin Invest. 2008;118:1277-90.

14. Viswanathan VK, Hodges $K$, Hecht G. Enteric infection meets intestinal function: how bacterial pathogens cause diarrhoea. Nat Rev Microbiol. 2009:7:110-9.

15. Costa LB, JohnBull EA, Reeves JT, Sevilleja JE, Freire RS, Hoffman PS, et al. Cryptosporidium-malnutrition interactions: mucosal disruption, cytokines, and TLR signaling in a weaned murine model. J Parasitol. 2011;97:1113-20.

16. Brown EM, Wlodarska M, Willing BP, Vonaesch P, Han J, Reynolds LA, et al. Diet and specific microbial exposure trigger features of environmental enteropathy in a novel murine model. Nat Commun. 2015;6:7806.

17. Mondal D, Minak J, Alam M, Liu Y, Dai J, Korpe P, et al. Contribution of enteric infection, altered intestinal barrier function, and maternal malnutrition to infant malnutrition in Bangladesh. Clin Infect Dis Off Publ Infect Dis Soc Am. 2012;54:185-92.

18. Black RE. Diarrheal diseases and child morbidity and mortality. Popul Dev Rev. 1984:10:141-61.

19. Checkley W, Epstein LD, Gilman RH, Black RE, Cabrera L, Sterling CR. Effects of cryptosporidium parvum infection in Peruvian children: growth faltering and subsequent catch-up growth. Am J Epidemiol. 1998;148:497-506.

20. Lee G, Paredes Olortegui M, Peñataro Yori P, Black RE, Caulfield L, Banda Chavez C, et al. Effects of Shigella-, Campylobacter- and ETEC-associated diarrhea on childhood growth. Pediatr Infect Dis J. 2014;33:1004-9.

21. Guerrant DI, Moore SR, Lima AA, Patrick PD, Schorling JB, Guerrant RL. Association of early childhood diarrhea and cryptosporidiosis with impaired physical fitness and cognitive function four-seven years later in a poor urban community in northeast Brazil. Am J Trop Med Hyg. 1999:61:707-13.

22. Lorntz B, Soares AM, Moore SR, Pinkerton R, Gansneder B, Bovbjerg VE, et al. Early childhood diarrhea predicts impaired school performance. Pediatr Infect Dis J. 2006;25:513-20.

23. Niehaus MD, Moore SR, Patrick PD, Derr LL, Lorntz B, Lima AA, et al. Early childhood diarrhea is associated with diminished cognitive function 4 to 7 years later in children in a northeast Brazilian shantytown. Am J Trop Med Hyg. 2002;66:590-3. 
24. Naylor C, Haque R, Mondal D, Buonomo E, Nayak U, Mychaleckyi J, et al. Environmental Enteropathy, Oral Vaccine Failure and Growth Faltering in Infants in Bangladesh. EBioMedicine. 2015. In Press.

25. Moore SR, Lima NL, Soares AM, Oria RB, Pinkerton RC, Barrett LJ, et al. Prolonged episodes of acute diarrhea reduce growth and increase risk of persistent diarrhea in children. Gastroenterology. 2010;139:1156-64.

26. DeBoer MD, Lima AAM, Oría RB, Scharf RJ, Moore SR, Luna MA, et al. Early childhood growth failure and the developmental origins of adult disease: do enteric infections and malnutrition increase risk for the metabolic syndrome? Nutr Rev. 2012;70:642-53.

27. Guerrant RL, Schorling JB, McAuliffe JF, De Souza MA. Diarrhea as a cause and an effect of malnutrition: diarrhea prevents catch-up growth and malnutrition increases diarrhea frequency and duration. Am J Trop Med Hyg. 1992;47:28-35.

28. Schaible UE, Kaufmann SHE. Malnutrition and infection: complex mechanisms and global impacts. PLoS Med. 2007;4, e115.

29. Wheeler JG, Sethi D, Cowden JM, Wall PG, Rodrigues LC, Tompkins DS, et al. Study of infectious intestinal disease in England: rates in the community, presenting to general practice, and reported to national surveillance. BMJ. 1999;318:1046-50

30. MacDougall L, Majowicz S, Dore K, Flint J, Thomas K, Kovacs S, et al. Under-reporting of infectious gastrointestinal illness in British Columbia, Canada: who is counted in provincial communicable disease statistics? Epidemiol Infect. 2008;136:248-56.

31. Gordon JE, Béhar M, Scrimshaw NS. Acute diarrhoeal disease in less developed countries: 1. An epidemiological basis for control*. Bull World Health Organ. 1964;31:1.

32. Platts-Mills JA, Babji S, Bodhidatta L, Gratz J, Haque R, Havt A, et al. Pathogenspecific burdens of community diarrhoea in developing countries: a multisite birth cohort study (MAL-ED). Lancet Glob Health. 2015:3(9):e564-75.

33. Kotloff KL, Nataro JP, Blackwelder WC, Nasrin D, Farag TH, Panchalingam S, et al. Burden and aetiology of diarrhoeal disease in infants and young children in developing countries (the Global Enteric Multicenter Study, GEMS): a prospective, case-control study. Lancet. 2013:382:209-22.

34. Platts-Mills JA, Operario DJ, Houpt ER. Molecular diagnosis of diarrhea: current status and future potential. Curr Infect Dis Rep. 2012:14:41-6.

35. Taniuchi M, Sobuz SU, Begum S, Platts-Mills JA, Liu J, Yang Z, et al. Etiology of Diarrhea in Bangladeshi Infants in the First Year of Life Using Molecular Methods. J Infect Dis. 2013;208(11):1794-802.

36. Lindenbaum J, Alam AK, Kent TH. Subclinical small-intestinal disease in East Pakistan. Br Med J. 1966:2:1616-9.

37. Colwell EJ, Welsh JD, Legters LJ, Proctor RF. Jejunal morphological characteristics in south vietnamese residents: A preliminary report. JAMA 1968;206:2273-6

38. Fagundes-Neto U, Viaro T, Wehba J, da Patricio FR S, Machado NL. Tropical Enteropathy (Environmental Enteropathy) in Early Childhood: a Syndrome Caused by Contaminated Environment. J Trop Pediatr. 1984;30:204-9.

39. Menzies IS, Zuckerman MJ, Nukajam WS, Somasundaram SG, Murphy B, Jenkins AP, et al. Geography of intestinal permeability and absorption. Gut. 1999:44:483-9.

40. Keusch GT, Denno DM, Black RE, Duggan C, Guerrant RL, Lavery JV, et al. Environmental enteric dysfunction: pathogenesis, diagnosis, and clinical consequences. Clin Infect Dis. 2014;59:S207-12.

41. Kosek M, Guerrant RL, Kang G, Bhutta Z, Yori PP, Gratz J, et al. Assessment of environmental enteropathy in the MAL-ED cohort study: theoretical and analytic framework. Clin Infect Dis. 2014;59:S239-47.

42. Kelly P, Menzies I, Crane R, Zulu I, Nickols C, Feakins R, et al. Responses of small intestinal architecture and function over time to environmental factors in a tropical population. Am J Trop Med Hyg. 2004;70:412-9.

43. Lunn PG, Northrop-Clewes CA, Downes RM. Intestinal permeability, mucosal injury, and growth faltering in Gambian infants. Lancet. 1991;338:907-10.

44. Campbell DI, Murch SH, Elia M, Sullivan PB, Sanyang MS, Jobarteh B, et al. Chronic $T$ cell-mediated enteropathy in rural west African children: relationship with nutritional status and small bowel function. Pediatr Res. 2003;54:306-11.

45. Kosek M, Haque R, Lima A, Babji S, Shrestha S, Qureshi S, et al. Fecal markers of intestinal inflammation and permeability associated with the subsequent acquisition of linear growth deficits in infants. Am J Trop Med Hyg. 2013:88:390-6.

46. Korpe PS, Petri Jr WA. Environmental enteropathy: critical implications of a poorly understood condition. Trends Mol Med. 2012;18:328-36.
47. Prendergast A, Kelly P. Enteropathies in the developing world: neglected effects on global health. Am J Trop Med Hyg. 2012;86:756-63.

48. Goto R, Panter-Brick C, Northrop-Clewes CA, Manahdhar R, Tuladhar NR. Poor intestinal permeability in mildly stunted Nepali children: associations with weaning practices and Giardia lamblia infection. Br J Nutr. 2002:88:141-9.

49. Weisz AJ, Manary MJ, Stephenson K, Agapova S, Manary FG, Thakwalakwa C, et al. Abnormal gut integrity is associated with reduced linear growth in rural Malawian children. J Pediatr Gastroenterol Nutr. 2012;55:747-50.

50. Lima NL, Soares AM, Mota RMS, Monteiro HSA, Guerrant RL, Lima AAM. Wasting and intestinal barrier function in children taking alanyl-glutaminesupplemented enteral formula. J Pediatr Gastroenterol Nutr. 2007:44:365-74.

51. Denno DM, VanBuskirk K, Nelson ZC, Musser CA, Hay Burgess DC, Tarr PI. Use of the lactulose to mannitol ratio to evaluate childhood environmental enteric dysfunction: a systematic review. Clin Infect Dis. 2014;59:S213-9.

52. Lee GO, Kosek P, Lima AAM, Singh R, Yori PP, Olortegui MP, et al. Lactulose: mannitol diagnostic test by HPLC and LC-MSMS platforms: considerations for field studies of intestinal barrier function and environmental enteropathy. J Pediatr Gastroenterol Nutr. 2014:59:544-50.

53. Peterson KM, Buss J, Easley R, Yang Z, Korpe PS, Niu F, et al. REG1B as a predictor of childhood stunting in Bangladesh and Peru123. Am J Clin Nutr. 2013;97:1129-33.

54. Kuss SK, Best GT, Etheredge CA, Pruijssers AJ, Frierson JM, Hooper LV, et al. Intestinal microbiota promote enteric virus replication and systemic pathogenesis. Science. 2011;334:249-52.

55. Srikanth CV, McCormick BA. Interactions of the Intestinal Epithelium with the Pathogen and the Indigenous Microbiota: A Three-Way Crosstalk. Interdiscip. Perspect. Infect. Dis. [Internet]. 2008 [cited 2016 Feb 24];2008, Available from: http://www.ncbi.nlm.nih.gov/pmc/articles/PMC2648619/

56. Blanton LV, Charbonneau MR, Salih T, Barratt MJ, Venkatesh S, Ilkaveya O, et al. Gut bacteria that prevent growth impairments transmitted by microbiota from malnourished children. Science. 2016:351:aad3311.

57. Subramanian S, Huq S, Yatsunenko T, Haque R, Mahfuz M, Alam MA, et al. Persistent gut microbiota immaturity in malnourished Bangladeshi children. Nature. 2014;510:417-21.

58. Kau AL, Planer JD, Liu J, Rao S, Yatsunenko T, Trehan I, et al. Functional characterization of IgA-targeted bacterial taxa from undernourished Malawian children that produce diet-dependent enteropathy. Sci Transl Med. 2015;7:276ra24

59. Semba RD, Shardell M, Sakr Ashour FA, Moaddel R, Trehan I, Maleta KM, et al. Child Stunting Is Associated with Low Circulating Essential Amino Acids. EBioMedicine [Internet]. [cited 2016 Feb 23]; Available from: http://www.sciencedirect.com/science/article/pii/S235239641630069X

60. Hashimoto T, Perlot T, Rehman A, Trichereau J, Ishiguro H, Paolino M, et al. ACE2 links amino acid malnutrition to microbial ecology and intestinal inflammation. Nature. 2012;487:477-81.

61. Condon-Paoloni D, Cravioto J, Johnston FE, De Licardie ER, Scholl TO. Morbidity and growth of infants and young children in a rural Mexican village. Am J Public Health. 1977:67:651-6.

62. Martorell R, Habicht JP, Yarbrough C, Lechtig A, Klein RE, Western KA. Acute morbidity and physical growth in rural Guatemalan children. Am J Dis Child. 1960;1975;129:1296-301.

63. Black RE, Brown KH, Becker S. Effects of diarrhea associated with specific enteropathogens on the growth of children in rural Bangladesh. Pediatrics. 1984:73:799-805.

64. Checkley W, Buckley G, Gilman RH, Assis AMO, Guerrant RL, Morris SS, et al. Multi-country analysis of the effects of diarrhoea on childhood stunting. Int J Epidemiol. 2008;37:816-30.

65. Pickering A, Djebbari H, Lopez C, Coulibaly M, Alzua ML. Effect of a communityled sanitation intervention on child diarrhoea and child growth in rural Mali: a cluster-randomised controlled trial. Lancet Glob Health. 2015;3:e701-11.

66. Pruss A, Kay D, Fewtrell L, Bartram J. Estimating the burden of disease from water, sanitation, and hygiene at a global level. Environ Health Perspect. 2002:110:537-42.

67. Checkley W, Gilman RH, Epstein LD, Suarez M, Diaz JF, Cabrera L, et al. Asymptomatic and symptomatic cryptosporidiosis: their acute effect on weight gain in Peruvian children. Am J Epidemiol. 1997;145:156-63.

68. Lee G, Pan W, Peñataro Yori P, Paredes Olortegui M, Tilley D, Gregory $M$, et al. Symptomatic and asymptomatic campylobacter infections associated with reduced growth in Peruvian children. PLoS Negl Trop Dis. 2013;7, e2036. 
69. Kabir I, Malek MA, Mazumder RN, Rahman MM, Mahalanabis D. Rapid catchup growth of children fed a high-protein diet during convalescence from shigellosis. Am J Clin Nutr. 1993;57:441-5.

70. Richard SA, Black RE, Gilman RH, Guerrant RL, Kang G, Lanata CF, et al. Catch-up growth occurs after diarrhea in early childhood. J Nutr. 2014;144: 965-71.

71. Richard SA, Black RE, Gilman RH, Guerrant RL, Kang G, Lanata CF, et al. Diarrhea in early childhood: short-term association with weight and longterm association with length. Am J Epidemiol. 2013;178:1129-38.

72. Onorato IM, Modlin JF, McBean AM, Thoms ML, Losonsky GA, Bernier RH. Mucosal immunity induced by enhanced-potency inactivated and oral polio vaccines. J Infect Dis. 1991;163:1-6.

73. Serazin AC, Shackelton LA, Wilson C, Bhan MK. Improving the performance of enteric vaccines in the developing world. Nat Immunol. 2010;11:769-73.

74. Levine MM. Immunogenicity and efficacy of oral vaccines in developing countries: lessons from a live cholera vaccine. BMC Biol. 2010;8:129.

75. Parker EPK, Kampmann B, Kang G, Grassly NC. Influence of enteric infections on response to oral poliovirus vaccine: a systematic review and metaanalysis. J Infect Dis. 2014;210:853-64.

76. Myaux JA, Unicomb L, Besser RE, Modlin JF, Uzma A, Islam AM, et al. Effect of diarrhea on the humoral response to oral polio vaccination. Pediatr Infect Dis J. 1996;15:204-9.

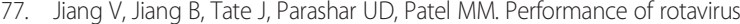
vaccines in developed and developing countries. Hum Vaccin. 2010;6:532-42.

78. Migasena S, Simasathien S, Samakoses R, Pitisuttitham P, Heath J, Bellini W, et al. Adverse impact of infections on antibody responses to measles vaccination. Vaccine. 1998;16:647-52.

79. Sheikh A, Shamsuzzaman S, Ahmad SM, Nasrin D, Nahar S, Alam MM, et al. Zinc Influences innate immune responses in children with enterotoxigenic escherichia coli-induced diarrhea. J Nutr. 2010;140:1049-56.

80. Lagos R, Fasano A, Wasserman SS, Prado V, Martin OS, Abrego P, et al. Effect of small bowel bacterial overgrowth on the immunogenicity of single-dose live oral cholera vaccine CVD 103-HgR. J Infect Dis. 1999;180:1709-12.

81. Cooper PJ, Chico ME, Losonsky G, Sandoval C, Espinel I, Sridhara R, et al. Albendazole treatment of children with ascariasis enhances the vibriocidal antibody response to the live attenuated oral cholera vaccine CVD 103-HgR. J Infect Dis. 2000;182:1199-206

82. Donowitz JR, Haque R, Kirkpatrick BD, Alam M, Lu M, Kabir M, et al. Small intestine bacterial overgrowth and environmental enteropathy in Bangladeshi children. mBio. 2016:7:e02102-15.

83. Valdez Y, Brown EM, Finlay BB. Influence of the microbiota on vaccine effectiveness. Trends Immunol. 2014:35:526-37.

84. Brown EM, Arrieta M-C, Finlay BB. A fresh look at the hygiene hypothesis: how intestinal microbial exposure drives immune effector responses in atopic disease. Semin Immunol. 2013;25:378-87.

85. Medzhitov R, Schneider DS, Soares MP. Disease tolerance as a defense strategy. Science. 2012;335:936-41.

86. Grantham-McGregor S, Cheung YB, Cueto S, Glewwe P, Richter L, Strupp B. Developmental potential in the first 5 years for children in developing countries. Lancet. 2007;369:60-70.

87. Patrick PD, Oriá RB, Madhavan V, Pinkerton RC, Lorntz B, Lima AAM, et al Limitations in verbal fluency following heavy burdens of early childhood diarrhea in Brazilian shantytown children. Child Neuropsychol J Norm Abnorm Dev Child Adolesc. 2005;11:233-44.

88. Watkins WE, Pollitt E. "Stupidity or worms": do intestinal worms impair mental performance? Psychol Bull. 1997;121:171-91.

89. Tarleton JL, Haque R, Mondal D, Shu J, Farr BM, Petri WA. Cognitive effects of diarrhea, malnutrition, and Entamoeba histolytica infection on school age children in Dhaka, Bangladesh. Am J Trop Med Hyg. 2006;74:475-81.

90. Berkman DS, Lescano AG, Gilman RH, Lopez SL, Black MM. Effects of stunting, diarrhoeal disease, and parasitic infection during infancy on cognition in late childhood: a follow-up study. Lancet. 2002;359:564-71.

91. Fischer Walker CL, Lamberti L, Adair L, Guerrant RL, Lescano AG, Martorell R, et al. Does childhood diarrhea influence cognition beyond the diarrheastunting pathway? PLoS One. 2012;7, e47908.

92. Walker SP, Wachs TD, Gardner JM, Lozoff B, Wasserman GA, Pollitt E, et al. Child development: risk factors for adverse outcomes in developing countries. Lancet. 2007;369:145-57.

93. Duflo E. Schooling and Labor Market Consequences of School Construction in Indonesia: Evidence from an Unusual Policy Experiment [Internet].
National Bureau of Economic Research; 2000 Aug. Report No.: 7860 Available from: http://www.nber.org/papers/w7860

94. Guerrant RL, Kosek M, Lima AAM, Lorntz B, Guyatt HL. Updating the DALYs for diarrhoeal disease. Trends Parasitol. 2002;18:191-3.

95. Institute for Health Metrics and Evaluation (IHME). GBD Compare [Internet]. 2016. Available from: http://vizhub.healthdata.org/gbd-compare

96. UNICEF. Joint Malnutrition dataset from UNICEF, World Bank and WHO [Internet]. 2016. Available from: http://data.unicef.org/nutrition/malnutrition.html

\section{Submit your next manuscript to BioMed Central and we will help you at every step:}

- We accept pre-submission inquiries

- Our selector tool helps you to find the most relevant journal

- We provide round the clock customer support

- Convenient online submission

- Thorough peer review

- Inclusion in PubMed and all major indexing services

- Maximum visibility for your research

Submit your manuscript at www.biomedcentral.com/submit
) Biomed Central 